ROCZNIKI HUMANISTYCZNE

Tom LXVII, zeszyt $10-2019$

DOI: http://dx.doi.org/10.18290/rh.2019.67.10-4

PRZEMYSŁAW JÓŹWIKIEWICZ

\title{
ЗВИЧАЙНА СПРАВА WALENTYNA WASIANOWYCZA W PRZEKŁADACH STUDENTÓW \\ - SUKCESY I PORAŻKI TRANSLATORYCZNE W ŚWIETLE DYDAKTYKI NAUCZANIA JĘZYKÓW OBCYCH
}

Звичайна справа, ukraiński film w reżyserii Walentyna Wasianowycza miał swą premierę w lutym 2013 r. Obraz jest debiutem reżysera, a zarazem współscenarzysty i jednego z autorów muzyki do filmu. Trwająca półtorej godziny tragikomedia to opowieść o psychiatrze Toliku, poszukiwaniu sensu życia, a pośrednio, poprzez pryzmat perypetii głównego bohatera, to swoisty spacer przez absurdy ukraińskiej rzeczywistości' ${ }^{1}$. Jednak to nie sam film, ocena jego wartości artystycznej bądź kwestie w nim poruszane są tematem niniejszego artykułu. Obraz W. Wasianowycza, a dokładniej warstwa słowna filmu, stanowi bazę materiałową i jest punktem wyjścia do rozważań na temat problematyki przekładu audiowizualnego, jak również do kwestii nauczania/ uczenia się/ pogłębiania znajomości języka ukraińskiego podczas wykonywania konkretnych zadań translatorskich.

\footnotetext{
Dr hab. PrzemysŁaw Jóźwikiewicz, prof. UWr - Zakład Ukrainistyki, Instytut Filologii Słowiańskiej Uniwersytetu Wrocławskiego; e-mail: przemyslaw.jozwikiewicz@uwr.edu.pl

${ }^{1}$ Główny bohater filmu Звичайна справа, psychiatra Tolik zostaje zwolniony z pracy. Z racji tego, że Tolik jest również niespełnionym poetą, wydarzenie to staje się dla niego okazją do rozpoczęcia nowego życia, właśnie na niwie literatury. Jednak by spełnić swe marzenia główny bohater (w tej roli Taras Denysenko) musi pokonać wiele życiowych pułapek... Pomaga mu w tym jego wierny przyjaciel Sławik (Witalij Linecki) wciągający Tolika w spiralę niesamowitych niekiedy zdarzeń. W ich wyniku psychiatra traci niemal wszystko, rozpada się również jego małżeństwo. Звичайна справа - tragikomedia produkcji ukraińskiej, rok produkcji-2012, premiera 7.02.2013 r., czas trwania: 88 min., reżyseria: Walentyn Wasianowycz, scenariusz: Walentyn Wasianowycz, Ija Myslicka, Maciej Sobieszczański, zdjęcia: Jurij Dunaj, muzyka: Kostiantyn Buszynski, Ołeksandra Morozowa, Walentyn Wasianowycz. Obsada: Taras Denysenko, Witalij Linecki, Łesia Samajewa, Semen Furman i in.
} 
Zanim przejdziemy do prezentacji, opisu i oceny tłumaczeń wykonanych przez studentów ukrainistyki Uniwersytetu Wrocławskiego (II rok cyklu magisterskiego w roku akademickim 2014/15) należy zastanowić się nad dwiema niezmiernie ważnymi kwestiami: 1) czym jest przekład audiowizualny $i$ jakie zagadnienia są dla tego rodzaju tłumaczeń istotne?, 2) w jaki sposób zajęcia z przekładu audiowizualnego wpisują się w realizację konkretnych zadań dydaktycznych, tzn. nauczania języka ukraińskiego na pewnym założonym poziomie.

Ad 1) Przekład audiowizualny to każdy rodzaj zabiegów translatorskich wykonywanych, jak pisze Teresa Tomaszkiewicz, na potrzeby ekranu ${ }^{2}$, czyli konkretne techniki tłumaczeniowe stosowane w kinie i telewizji. Definicji, jak i wariantów samej nazwy tego rodzaju tłumaczeń jest więcej (zob. przyp. 5). Taka różnorodność nazewnicza wiąże się z faktem, że jest to względnie nowa, ale bardzo dynamicznie rozwijająca się sfera translatoryki. Wprawdzie o funkcjonowaniu „przekładu audiowizualnego” można mówić już w odniesieniu do początków kina niemego ${ }^{3}$, jednak prawdziwe zainteresowanie tłumaczeniem na potrzeby mediów, również od strony teorii samego zagadnienia, datować należy na połowę lat 90 . ubiegłego stulecia.

Problemów poruszanych na konferencjach ${ }^{4}$ poświęconych przekładowi audiowizualnemu jest wiele. Teoretycy i praktycy przekładu spierają się w kwestii samej nazwy ${ }^{5}$ dyscypliny, wyższości metod tłumaczeniowych ${ }^{6}$, narzędzi badawczych, strategii translatorskich przyjmowanych podczas tłumaczenia dla konkretnego medium itd. Faktem jest, że od czasu Konferencji Wersalskiej, która

${ }^{2}$ T. Tomaszkiewicz, Przekład audiowizualny, Warszawa: Wydawnictwo Naukowe PWN 2008, s. 10.

${ }^{3} \mathrm{~W}$ japońskim kinie niemym funkcjonowała osoba benshi, czyli swego rodzaju tłumacza, którego zadaniem było łączenie w całość krótkich scenek filmowych, wypełnianie czasu między zmianami rolek z taśmą filmową, czytanie podpisów pojawiających się na ekranie, niekiedy wyjaśnianie widzom zachodzących wydarzeń, a nawet ich interpretacja; benshi byli zatem niejako współtwórcami filmu; zob. K. LosKA, Benshi jako współautor filmu, „Kwartalnik Filmowy” 2007, nr 57, s. 59-65.

${ }^{4} \mathrm{~W}$ ostatnich latach np. „Points of View in Language and Culture: Audiovisual Translation”, Kraków UJ, 2011; „Przekład jako akt komunikacji międzykulturowej”, Poznań UAM, 2011; „Przekład pod lupą”, Warszawa UW, 2013; „Przestrzenie przekładu”, Sosnowiec UŚ, $2015 \mathrm{i}$ in.

${ }^{5} \mathrm{~W}$ języku polskim na określenie tego rodzaju przekładu funkcjonuje kilka nazw; najbardziej przyjął się termin „przekład audiowizualny”. Pod takim właśnie tytułem w 2006 r. ukazała się książka Teresy Tomaszkiewicz, jednak już sama autorka w swej monografii używa zamiennie pojęć „tłumaczenie audiowizualne”, „tłumaczenie filmowe”, „tłumaczenie telewizyjne” i wreszcie „tłumaczenie na potrzeby ekranu”. To nie wszystkie określenia, które dotyczą tej dziedziny przekładu. Wspomnieć tu można o „tłumaczeniu filmów” A. Belczyka, „tłumaczeniu filmowym” G. Adamowicz-Grzyb czy ,tłumaczeniu dialogów filmowych” A. Pisarskiej i T. Tomaszkiewicz. 
stała się impulsem dla rozwoju przekładu w Europie i Ameryce, jest to kolejny etap w historii światowej translatoryki.

Sytuacja przekładu audiowizualnego w Polsce jest dynamiczna, a przez to niezmiernie interesująca. Wiele w tej dziedzinie dzieje się zarówno na poziomie teorii i badań nad problemem, jak i w planie praktycznym, a więc ilości i różnorodności wykonywanych tłumaczeń. Badania nad tłumaczeniami wykonywanymi na potrzeby mediów trwają od ponad 20 lat, a wśród polskich uczonych zajmujących się tą problematyką należy wymienić m.in. Teresę Tomaszkiewicz, Agnieszkę Szarkowską, Arkadiusza Belczyka, Grażynę Adamowicz-Grzyb i in.

Przez zachodnich teoretyków przekładu (np. Henrika Gottlieba) Polska, jak i inne kraje Europy Środkowej i Wschodniej, nie do końca zresztą słusznie, zaliczana jest do grupy voice-over, tzn. krajów, w których przeważa tłumaczenie oparte na lektorze odczytującym przetłumaczoną listę dialogową z pewnym opóźnieniem względem oryginalnej ścieżki dźwiękowej. Jednak nie można się już godzić z takim rodzajem klasyfikacji, bowiem obecna sytuacja na polskim rynku medialnym diametralnie różni się od tej sprzed kilku jeszcze lat. O ile w latach 90. polski rynek medialny rzeczywiście odpowiadał tego rodzaju przyporządkowaniu (produkcja telewizyjna, VHS), o tyle dzisiaj w polskich mediach obecne są wszystkie typy przekładu audiowizualnego: w telewizji - głównie wersja lektorska (niekiedy z podziałem na lektora mężczyznę i kobietę; kobiety czytają również większość filmów przyrodniczych), ale i dubbing (animacje dla dzieci, filmy dla młodzieży) czy podpisy (np. w filmach muzycznych, wersje dla osób niesłyszących), osobną kwestią jest obecność na ekranie tłumacza migowego czy audiodeskrypcja ${ }^{7}$; w kinie - filmy z podpisami i dubbingowane (obrazy animowane i przygodowe, np. wysokobudżetowe filmy z bohaterami uniwersum Marvela, filmy oparte na prozie Tolkiena, Gwiezdne Wojny itd.); w produkcjach na nośnikach DVD do wyboru jest niemal zawsze wersja oryginalna, podpisy, lektor i coraz częściej dubbing; w produkcji dostępnej w internecie - przede wszystkim podpisy i voice-over.

Od lat toczą się dywagacje na temat tego, który sposób prezentacji materiału wizualnego i towarzyszącej mu „obcej” warstwy językowej jest lepszy, pełniejszy, mniej inwazyjny. Ostatecznego rozwiązania tego sporu nie ma, choć wielu

\footnotetext{
${ }^{6}$ Wyróżnić należy 3 główne metody wykorzystywane w tłumaczeniu filmów w Polsce: voice over, podpisy, dubbing, z których każda ma swoich wiernych zwolenników, jak i zagorzałych przeciwników. Wprawdzie w telewizji nadal dominuje wersja lektorska, a w kinach podpisy, jednak dubbinguje się coraz więcej produkcji; dubbing filmów animowanych stał się już dobrą tradycją, podobnie jak i filmów dla młodzieży czy hitów kinowych.

${ }^{7}$ Więcej na ten temat zob. A. Szarkowska, Przeklad audiowizualny w Polsce-perspektywy i wyzwania, „Przekładaniec” 20, Kraków: Wydawnictwo UJ 2008, s. 18-20, 22.
} 
fachowców mimo wszystko skłania się ku dubbingowi jako metodzie najlepszej. Wydaje się jednak, że najbardziej racjonalny jest tu pogląd, którego reprezentantem jest Jorge Diaz-Cintaz. Ten bowiem, zapytany o wyższość jednej z metod przekładu, stwierdził: ,[...] dubbing i podpisy - koniec dylematu”.

$\mathrm{Z}$ uwagi na ograniczenia związane ze złożonością procesu dubbingu ${ }^{9}$ czy nawet zastosowania wersji lektorskiej projekt, który wykonywali studenci, a o którym w dalszej części artykułu, musiał ograniczyć się tylko do wersji z podpisami, jako najrozsądniejszej metodzie prezentacji warstwy dialogowej filmu Звичайна справа.

Ad 2) W jaki zatem sposób projekt opracowania filmu w reżyserii W. Wasianowycza wykonywany przez studentów na potrzeby polskiego widza (projekt, dodajmy, obudowany adekwatnymi do stanu ich wiedzy translatorycznej informacjami z zakresu przekładu, a zwłaszcza przekładu audiowizualnego przekazywanymi podczas zajęć i samodzielnej lektury prac z tej dziedziny) wpisuje się w proces nauczania / uczenia się języka ukraińskiego na poziomie odpowiadającym założeniom programowym dla II roku studiów magisterskich?

Proces przygotowania podpisów nie jest wprawdzie tak skomplikowany i czasochłonny jak dubbing, jednak również wymaga wykonania wielu złożonych czynności ${ }^{10}$, których realizacja $\mathrm{z}$ całą pewnością nie byłaby możliwa, gdyby nie pewien opanowany już zakres wiedzy, ale i wymóg dalszego rozwoju narzucany przez konkretne sytuacje zaistniałe w trakcie opracowania filmu. Rodzaj i wachlarz wykorzystywanych kompetencji językowych uzależniony jest od czynności związanych z poszczególnymi etapami pracy ${ }^{11}$ nad filmem.

Pierwszą z szeregu czynności wykonywanych podczas pracy nad projektem było przynajmniej jednokrotne obejrzenie całego filmu i uważne dwu-, trzykrotne zapoznanie się z przydzielonym do opracowania fragmentem obrazu. Pozwoliło to na wychwycenie sytuacji, z którymi na dalszych etapach mogły wiązać się pewne problemy (niewyraźne wypowiedzi bohaterów, zagłuszanie ich przez efekty dźwiękowe, wiersze czytane przez głównego bohatera itd.). Z racji tego,

${ }^{8}$ J. Diaz-Cintas, Dubbing or Subtitling: the Eternal Dilemma, „Perspectives: Studies in Translatology" 1999, nr 7, s. 38.

${ }^{9}$ Według T. Tomaszkiewicz i innych autorów, dubbing to najbardziej złożony proces opracowania filmu składający się z aż jedenastu faz. Jednak to nie złożoność tego procesu, ale przede wszystkim problemy z odpowiednim wyposażeniem technicznym legły u podstaw decyzji o opracowaniu tylko podpisów do filmu.

${ }^{10}$ Przygotowanie metryki programu lub filmu, weryfikacja zgodności oryginału z listą dialogową, wykonanie kopii roboczej itd. Zob. T. Tomaszkiewicz, Przeklad audiowizualny, Warszawa: Wydawnictwo Naukowe PWN 2008, s. 106-107, 114-115.

${ }^{11}$ Zob. m.in. P. Jóźwikiewicz, Przekład a proces nauczania języka ukraińskiego, „Теopiя і практика викладання української мови як іноземної” 2007, nr 2, s. 212-218. 
że studenci nie mieli dostępu do ukraińskojęzycznej listy dialogowej ${ }^{12}$, koniecznością było spisanie ze słuchu wypowiedzi pojawiających się w przydzielonych fragmentach filmu. Było to niewątpliwie jedno z trudniejszych zadań i z tego też względu nieodzowna okazała się grupowa weryfikacja tekstów; etap ten był bardzo pomocny, gdyż podczas konfrontacji rozwiano wiele wątpliwości (rozwijane kompetencje: słuchanie i pisanie).

W dalszej kolejności studenci przystępowali do tłumaczenia na język polski spisanych ze słuchu fragmentów listy dialogowej. Tłumaczenia weryfikowane były zarówno przez prowadzącego zajęcia, jak i grupę: omawiano je, proponowano alternatywne rozwiązania, argumentowano konieczność dokonywania określonych wyborów translatorskich itd. (rozwijane kompetencje: tłumaczenie tekstu na język ojczysty).

Przekształcenie tekstu tłumaczenia w podpisy filmowe wymaga od tłumacza szczególnej uwagi i umiejętności. Ogólnie przyjętym standardem stosowanym w podpisach do filmu są dwie linie tekstu zawierające do 38 znaków w wersie. Nieskomplikowane, wydawałoby się, zadanie urasta jednak do sporych rozmiarów problemu, jeśli weźmiemy pod uwagę, że należy przy tym uwzględnić czas, w którym przeciętny widz odczytuje 2 wiersze tekstu (ok. 2-3 sekundy), przebieg poszczególnych scen ${ }^{13}$ oraz tempo wypowiedzi bohatera na ekranie; tu, zwłaszcza w filmach opartych na dużej ilości dialogów, niejednokrotnie mamy do czynienia z sytuacjami, w których postacie ekranowe w krótkim czasie przekazują wiele istotnych informacji, czy też scenami, kiedy jednocześnie wypowiada się klika osób. Trudność związana z koniecznością dokonania pewnych wyborów jest tu aż nadto zauważalna. Szacuje się, co potwierdza wielu autorów, m.in. T. Tomaszkiewicz, że w procesie kondensacji tekstu wyjściowego następuje utrata nawet do $40 \%$ pierwotnego tłumaczenia, co oczywiście kompensowane jest w pewnym

${ }^{12}$ Sytuacja, w której tłumacz filmowy nie ma dostępu do oryginalnej listy dialogowej zdarzają się dziś już dość rzadko. Nieco inaczej wygląda sytuacja na ukraińskim rynku kinematograficznym. Filmy ukraińskie (pomijam tu kwestię złej kondycji kinematografii ukraińskiej) nieczęsto przebijają się poza granice Ukrainy (wyjątkiem mogą tu być kraje byłego ZSRR; problemów nie ma, jeśli film jest rosyjskojęzyczny), stąd brak praktyki udostępniania listy dialogowej. Obraz Wasianowycza jest tu w pewnym sensie chlubnym wyjątkiem, bowiem został on „wyposażony” w podpisy w języku angielskim. Nie zmienia to jednak faktu, że studenci nie mieli dostępu do listy dialogowej w języku ukraińskim, zatem przed przystąpieniem do tłumaczenia należało ją opracować.

${ }^{13}$ Należy pamiętać, że warstwa werbalna filmu (w pewnym stopniu dotyczy to, rzecz jasna, również podpisów) współgra $\mathrm{z}$ tym, co dzieje się na ekranie. Tłumacz musi zatem zwracać uwagę nie tylko na kwestie wypowiadane przez bohaterów filmu, ale również uwzględniać inne czynniki, np. ogólną sytuację na ekranie, gestykulację, mimikę bohaterów, jak również takie elementy, jak dźwięk, muzyka, czasem nawet scenografia. 
stopniu obecnością elementów redundantnych. Przed takimi wyborami stanęli również studenci opracowujący listę dialogową filmu Звичайна справа.

Ostatnim etapem, ściśle powiązanym z opisanymi wcześniej czynnościami, jest proces synchronizacji podpisów w wybranym programie komputerowym. Jest ich wiele, studenci korzystali głównie z dwóch: SubEdit Player ${ }^{14}$ i Subtitle Workshop ${ }^{15}$. Połączenie poszczególnych podpisów oraz ostateczna weryfikacja całości (to niezwykle ważny etap prac pozwalający na wychwycenie błędów w synchronizacji, niepotrzebnych znaków, błędów w pisowni czy interpunkcji, określenie liczby wersów) kończy proces tworzenia podpisów do filmu.

Reasumując, należy stwierdzić, że opracowywany projekt stanowił dla studentów duże wyzwanie. Prace nad stworzeniem produktu końcowego, a więc podpisów zsynchronizowanych z odpowiednimi partiami obrazu, wymagał od nich wykazania się odpowiednimi umiejętnościami przede wszystkim w zakresie rozumienia i percepcji warstwy dźwiękowej filmu, poprawnej pisowni, a w efekcie - tłumaczenia tekstu obcego na język polski i jego dostosowania do wymogów audiowizualnych.

Звичайна справа (w tłumaczeniu studentów: „Nic nadzwyczajnego”) nie był filmem łatwym do opracowania. Obraz cechuje nie tylko duża liczba dialogów, ale i obszerne monologi narratora i zarazem głównego bohatera - Tolika. Z tego względu podczas opracowywania polskiej wersji filmu należało dokonać wielu zabiegów kompensacyjnych. Dodatkową trudność stanowił fakt, że Tolik w kilku scenach recytuje swoje wiersze, które również należało przetłumaczyć zgodnie z kanonami sztuki translatorskiej. Pewne problemy stwarzała także obecność surżyka ${ }^{16}$.

Film podzielono na 10 dziewięciominutowych fragmentów. Konsekwencją takiego rozwiązania kwestii podziału materiału była zróżnicowana ilość tekstu przypadającego na poszczególne osoby.

\footnotetext{
${ }^{14}$ Program typu freeware, do pobrania np. ze strony http://subedit-player.softonic.pl/ (dostęp: 12.09.2015).

${ }^{15} \mathrm{http}: / /$ subworkshop. sourceforge.net/ (dostęp: 12.09.2015).

${ }^{16}$ Surżyk - ogólna ukraińska nazwa na mieszaninę dwóch lub więcej języków; w praktyce tym mianem określa się występującą na Ukrainie nienormatywną odmianę języka ukraińskiego będącą swoistym amalgamatem języków ukraińskiego i rosyjskiego. Więcej zob. Украӥнська мова. Енциклопедія, Київ: Вид-во „Українська енцклопедія” ім. М.П. Бажана 2004, s. 665 lub w wielu publikacjach na ten temat, m.in. Л.Т. МАсенко, Суржик: між мовою і язиком, Київ: Видавничий дім «Києво-Могилянська академія» 2011.
} 


\section{PERCEPCJA FILMU}

Pierwsze trudności w opracowaniu filmu pojawiły się już na etapie jego oglądania, a później spisywania ze słuchu warstwy dialogowej. Dużo zamieszania wprowadzały efekty dźwiękowe zagłuszające wypowiedzi bohaterów, rozmowy telefoniczne, nakładanie się głosów bohaterów, niewyraźna artykulacja (spowodowana np. jednoczesnym spożywaniem posiłku przez mówiącego lub będąca efektem pijaństwa), surżyk, np.

Будемо (............) торгувати гівно ${ }^{17} . /$ таки/ $/ 18$

Схоже ичей нероба (.............) і чекає на диво. Чекає вже 40 років. /добряче засів у мені/

Подивись на ц̧их ідіотів, які по черзі (.............). /входять на сцену/

Думаєщ у мене на душі ясно? (.............) Ти не переживай, бомж собі знаде новий велосипед. /Не хоче гівно зійти./

Я абсолютно спокійний, (............) ... поверху, а падаючи буду кричати 'Маша я тебе люблю!' Пєтя, Пєтя, иче я... /моє тіло втрачає вагу, я не чую.../

Давай (.............) /швидше/ иче він, по голові (.............), /вдарив/ гадюка!

Istota tej swoistej „głuchoty" tkwi, jak się wydaje, w niedostatecznym opanowaniu języka, słabym osłuchaniu się, niezbyt dobrze rozwiniętej umiejętności kojarzenia i rozróżniania dźwięków. Należy się jednak cieszyć, że sytuacji takich nie było dużo i że dotyczyły one w głównej mierze jednej osoby.

Drugim poważnym problemem pojawiającym się na początkowym etapie obróbki filmu były błędy powstałe podczas spisywaniu oryginalnej listy dialogowej

\footnotetext{
${ }^{17}$ Zapis przytaczanych w całym artykule przykładów jest oryginalny (w takiej postaci swe teksty przesyłali studenci), dotyczy to zarówno warstwy słownej, jak i interpunkcji. Wykropkowane fragmenty to kwestie sprawiające studentom problemy percepcyjne. Autor niniejszego artykułu nie ingerował w strukturę tekstów studenckich (poza podkreśleniami, np. w części dotyczącej błędów ortograficznych czy literówek. Te same fragmenty tekstów studenckich, jeśli pojawiły się w dalszej części artykułu, np. służąc za ilustrację procesu tłumaczenia, również przytaczane były w postaci oryginalnej, jednak obecne w nich błędy nie były już wskazywane, np. w pierwszej linijce wiersza: Поса ранкова, на весняних травах.).

${ }^{18} \mathrm{~W}$ nawiasach ukośnych zamieszczono elementy, których studenci nie byli w stanie rozszyfrować.
} 
filmu. Można je zebrać w dwóch głównych grupach: błędów ortograficznych (gramatycznych) oraz tzw. literówek.

Błędy ortograficzne (gramatyczne):

Життя ㄲюдьського ${ }^{19}$ в дивнім світі цим,

Кінець один для всіх.

А ни бладь, давай велосипед!

Сто п’ятьдесят грамів конічку.

Нероби нагороджуєтся гарбом, щоб всі про ие знали і показували пальиями. Я візму тебе в компаньони.

[...] якщо інтуічія трактує послання негативно тоді розум намагається їх ігнорувати [...]

А вони згущенку в найблищий кіоск за пів иіни, якраз на дозу вистарчає, а наступного дня знову тут як на роботу.

Всі мої друзі дивним чином кудиць зникли, лишився тільки Славік.

Твоє здоровя Таляне.

Ти реально врятував життя иіï собачої принцесі, а вона замість 'дякую' залютила тобі по писку.

Мне хочется нову машину.

Головною темою британьських казок є праия.

Тексти нам пишуть копірайтери, одяг підберають стилісти, кожен день інший образ, а зараз, вибач, обов'язок кличе.

${ }^{19}$ Poprawny zapis wykazanych błędów ortograficznych (gramatycznych) i literówek: людського, цім, ну блядь, п'ятдесят, конячку, нагороджується горбом, візьму, компаньйони, інтуйчія, найближчий, за півціни, вистачає, кудись, здоров'я, цій собачій, мені хочеться, британських, підбирають, патріарх, психіатрії, відповідей, бородою, нічого, роса, купив, академію, взуття, обкладиниі, ну, будь, якийсь. 


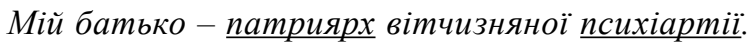

3 кожним днем у поштовій скринці все більше рекламних листівок $і$ жодних відповіді з редакиіï.

Пам'ятаю, иеей такий довгий з бородом.

Literówki:

Коли я закохалася, я три тижні нічіго не їла.

Поса ранкова, на весняних травах.

Думаєш він його купиб?

Мій батько патриярх вітчизняної психіартії.

Попрацюєи у мене рік, можеш захистити дисертацію, підеш угору, ну, наприклад в ададемію до татуся.

Чому чиновники їздять на дорогих автомобілях, а наші діти на мають бзуття, щзоб піти до школи?

Можеш надрукувати його на окладиниі своєї майбутньої книжки.

Ho тодi, бидь ласка, прочитайте якись свій віри.

Obecność literówek w tego typu opracowaniach nie dziwi, zastanawiająca jest natomiast tak duża liczba kardynalnych błędów ortograficznych/gramatycznych (znak miękki, apostrof, stopniowanie przymiotników, niewłaściwa fleksja itd.). Wydaje się, że takich pomyłek nie powinni już popełniać studenci II roku studiów magisterskich.

\section{TŁUMACZENIE}

Właściwy i najistotniejszy etap pracy nad projektem stanowiło tłumaczenie na język polski spisanej uprzednio listy dialogowej. Nabyte podczas ponad 4 lat nauki umiejętności językowe oraz świadome poszerzanie wiedzy z zakresu 
tłumaczeń podczas zajęć oferowanych w bloku translatorycznym stanowiły niemal gwarancję wykonania ciekawych przekładów, choć i tutaj nie obyło się bez trudności, wpadek i lapsusów.

Do tych pierwszych zaliczyć należy m.in. poniższe tłumaczenia:

$\mathrm{O} .{ }^{20}$ Але для нашого віку, ие звичайна справа.

P. Ale w naszym wieku, to nic nadzwyczajnego.

О. ЗВИЧАЙНА СПРАВА

P. NIC NADZWYCZAJNEGO

О. Коли стаєш дорослим, розумієш, що можливі варіанти.

P. Kiedy dorastasz, pojmujesz, że masz wybór.

О. Вірші на сьогоднішній день неліквідний товар.

P. Dzisiaj nie ma popytu na wiersze.

О. Нероби нагороджуєтся гарбом, щоб всі про це знали і показували пальиями.

P. Leni nagradza się garbem, żeby wszyscy się o tym dowiedzieli i wytykali palcami.

О. Це наша з тобою весільна тарілочка.

P. To nasz wspólny weselny talerzyk.

О. Я вже рік живу в иьому смітнику, я залишаю нашу роздувбану машину за кілометр від театру, щоби ніхто ї̈ не бачив.

P. Już rok mieszkam w tej dziurze, nasz rozpadający się samochód zostawiam kilometr od teatru, żeby nikt go nie zobaczyt.

О. Кожен раз ие відбувалося за однаковим сиенарієм; июю п'єсу я знав напам'ять і може тому сам скандал мене не дуже зачіпав.

P. Za każdym razem odbywa się to wedtug tego samego scenariusza; tę sztukę znatem na pamięć i może dlatego sama awantura nie bardzo mnie obchodziła.

О. А він у нас академік.

P. Jest czlonkiem Akademii Nauk.

О. Правильно, ти мій розумник, розумник ти мій. Красень ти мій.

P. Dobrze mówisz mój madralo, madralo ty mój. Przystojniaku ty mój.

${ }^{20} \mathrm{O}$ - oryginał, $\mathrm{P}$ - przekład 
О. Ще я подумав, все таки правда, щзо душа жива після смерті.

P. I pomyślałem, że to jednak prawda, że dusza nie umiera.

Przytoczone przykłady tłumaczeń świadczą o pomysłowości ich autorów, uwadze, warsztacie i umiejętności unikania ,zastawionych” przez tekst źródłowy pułapek; odznaczają się one zastosowaniem ciekawych rozwiązań, zarówno w obszarze wprowadzanych transformacji, jak i na poziomie leksykalnym oraz gramatycznym. Cieszą niewątpliwie rozwiązania, które nie są li tylko rezultatem poszukiwań najprostszego ekwiwalentu, ale wskazują na „obycie” z językiem, przemyślenie i dobór wariantów, wreszcie swoistą, „żyłkę” tłumacza (np. Коли стаєш дорослим, розумієш, щу можливі варіанти - Kiedy dorastasz, pojmиjesz, ż masz wybór; Bipшi на сьогоднішній день неліквідний товар - Dzisiaj niе та роруtи па wiersze; Ще я подумав, все таки правда, щуо душа жива після смерті - I pomyślatem, że to jednak prawda, że dusza nie umiera). Warta uwagi jest czujność młodych adeptów ukrainistyki, którzy stanęli na wysokości zadania i np. z ukraińskiego rzeczownika академік nie uczynili studenckiej bursy.

Studenci mieli oczywiście problemy z pewnymi partiami tekstu i ich tłumaczeniem, a było to zauważalne m.in. w prezentowanych poniżej fragmentach:

О. Люди бігають по крамницях, купують продукти, підтримують товаробіг.

P. Ludzie biegaja po straganach, kupuja prezenty, podtrzymuja handel.

О. Би ж за фахом - психотерапевт.

P. Z zawodu jest Pan terapeuta.

О. Мій батько - патриярх вітчизняної психіартіі.

P. Moj ojciec jest dyrektorem państwowego zakładu psychiatrycznego.

О. Коли прийтов час обирати професію, я мріяв бути поважним як тата і талановитим як брат.

P. Kiedy musiatem obrać zawód, chciałem być poważny jak ojciec i utalentowany jak brat.

О. Я виписував рецепти і писав вірші на лікарняних бланках.

P. Wystawiałem recepty i układałem wiersze na lekarskich blankietach.

О. Навіщо потрібні друзі дорослій людині? Може для того, щуоб спостерігати їхн життєві неудачі $і$ почувати себе щасливим і реалізованим, а може для того, щьоб заповнювати порожницю, яка утворилася під час невдалого сімейного життя або для того, щуоб просто спалити надлишок вільного часу. 
P. Po co sa potrzebni przyjaciele dorostemu człowiekowi? Może po to, żeby obserwować ich życiowe niepowodzenia i przy tym czuć się szczęśliwym i zrealizowanym, a może po to, żeby wypetnić próżnię, która utworzyła się podczas nieudanego rodzinnego życia albo po to, żeby prosto spalić nadmiar wolnego czasu.

О. Страх самотності, страх юрби, ідеї, що відрізняються від загально прийнятих, страх божевілля, залізничних колій, лисих людей. Страх незрозуміти сенс прочитаного, страх дивитись на небо. Кількість фобій невпинно зростає. Я боюся стати колекиіонером на потребу, котрий стане сенсом мого життя.

P. Lẹk samotności, lẹk ttumu, idei, co różni siẹ od ogólnoprzyjętych, lẹk wariacji, dróg kolejowych, tysych ludzi. Lẹk nie rozumieć sens przeczytanego, lek patrzeć na niebo. Ilość fobii nieustannie rośnie. Boję się zostać kolekcjonerem na potrzebę, który stanie się sensem mojego życia.

О. Ми наркозалежні люди є повноцінними членами суспільства і вимагаємо до себе відповідного відношення.

P. My uzależnieni od narkotyków ludzie jesteśmy pełnowartościowymi członkami społeczeństwa i wymagamy wobec siebie odpowiedniego stosunku.

О. Святославе Володимировичу, час розпочинати! Ну давайте розпочнем.

P. Swiatostawie Wołodymyrowyczu, naszedt czas rozpoczać. Nu dawajcie rozpoczniemy.

О. Прости нас грішних, Господи!

P. Wybacz nas, grzesznych, Boże!

О. Ласкотно. Ти що, хочеш другу дитину?

P. Łaskoczesz. Ty co, chcesz zrobić jeszcze jedno dziecko?

О.

P. Na cześć twojego 80-lecia napisatem wiersz.

Wśród najczęstszych ,grzechów” translatorskich, których zaprezentowane przykłady są jedynie częścią, wymienić należy m.in. stosowanie kalk językowych, zastosowanie nieprawidłowej fleksji i składni, nadinterpretacje semantyczne, nieodpowiedni szyk zdania czy zwyczajną nietrafność przy doborze ekwiwalentów w języku $\mathrm{B}$, prowadzącą częstokroć do niezrozumienia czy dwuznaczności. Pewien niesmak, a może nawet dozę niedowierzania (jak na tym etapie studiów można popełniać aż takie błędy?), wywołują choćby fragmenty: Люди бігають по крамнииях, купують продукти, підтримують товаробіг - Ludzie biegaja po straganach, 
kupuja prezenty, podtrzymuja handel (zamiast np. 'wspierają handel'); $\underline{\text { Cmpax }}$ самотності, страх юрби, ідеї, що відрізняються від загально прийнятих, страх божевілля, залізничних колій, лисих людей. Страх незрозуміти сенс прочитаного, страх дивитись на небо. Кількість фобій невпинно зростає - Lęk samotności, lęk tlumu, idei, co różni siẹ od ogólnoprzyjętych, lẹk wariacji, dróg kolejowych, tysych ludzi. Lẹk nie rozumieć sens przeczytanego, lekk patrzeć na niebo. Ilość fobii nieustannie rośnie (zamiast np. 'lęk przed...'); Святославе Володимировичу, час розпочинати! Ну давайте розпочнем-Swiatostawie Wołodymyrowyczu, naszedt czas rozpoczać. Nu dawajcie rozpoczniemy (zamiast np. 'czas zaczać', 'Zaczynamy!'); Прости нас грішних, Господи! - Wybacz nas, grzesznych, Boże! (zamiast np. 'Przebacz nam, grzesznikom').

Szczególne miejsce w procesie tłumaczenia listy dialogowej filmu zajmują przekłady wierszy „autorstwa” głównego bohatera stanowiące niejako komentarz do wydarzeń rozgrywających się na ekranie:

a)

О. Поса ранкова, на весняних травах.

Мені про вік короткі нагадала.

Життя людьського в дивнім світі ичим,

Кінець один для всіх.

Не встигли яблоні як слід і розцвісти

Вже пелюстки на землю опадають.

P. Rosa poranna, na wiosennych trawach.

O wieku krótkim, mi opowiadała.

Ludzkie życie na tym dziwnym świecie.

Koniec taki sam dla wszystkich.

Jabłonie rozkwitnać nie zdażyły,

A już na ziemię płatki opadaja.

b)

О. Ми нагонимо смутку і суму, чорним трунком наповнені буття.

Ми не здійснені людській думи, ми останні краплині життя.

Ми музики людської печалі, стукіт серця і пісня журби,

на неведені з витку спіралі, кроків людства, нестерті сліди.

P. Okryci mrocznymi woalami, napetnieni ciemnościa goryczy,

jesteśmy niezaspokojonymi ludzkimi myślami, ostatnimi kroplami bytowej słodyczy.

Jesteśmy muzykami ludzkiej rozpaczy, stukotem serca i gorzkimi pieśniami. 
A gdy spirala egzystencji o nas nie zahaczy, nasze kroki pozostana nieśmiertelnymi śladami.

c)

О. Я у сльозах води мов біле полотно хвилюлюся з потоком. Стій. Затули мене долонями од сонця. Заколиш мене на білих грудях сну, сповивщи пеленами довгих вій і промовчи вустами до чола, розрадуй віль, самотність хвилинкову... в пустій кімнаті ...слова, щуо ти мене ніколи не покинеш.

P. We łzach wody, niby czyste płótno, kołyszę się z ruczajem. Stój. Dtońmi swymi zakryj mnie przed stońcem. I ukołysz na białych piersiach snu, spowiwszy dtugich rzęs całunem i przylgnij milczeniem do czoła, pociesz mój ból, samotność chwilowa... W pustym pokoju rozbrzmiały słowa, że nigdy mnie nie zostawisz.

d)

О. Метилок сів у мене на потилиці. Метелик сів і там сидить.

Сидить метелик там і дивится як гарно на потилиці сидить.

Мені непогано і нелюбо, незрозуміла от земля.

Метелик просто переплутав де синя квітка а де я.

Метелик просто переплутав де синя стіна а де я.

P. Motylek usiadt na moim ramieniu. Usiadt $i$ siedzi.

Siedzi motylek i patrzy, jak miło siedzieć na ramieniu

Nie jest mi źle ani dobrze, taka niezrozumiała historia

Motylek po prostu pomylit niebieski kwiatek ze mna.

Motylek po prostu pomylił niebieska ścianę ze mna.

Tłumaczenie poezji zaliczane jest do najtrudniejszych tłumaczeń pisemnych, choć większość teoretyków i praktyków przekładu opowiada się w tym przypadku raczej za adaptacją aniżeli przekładem. Abstrahując od tego sporu, przekazanie sensów i treści z języka obcego na język rodzimy w obrębie tekstu tak hermetycznego pod różnymi względami jak wiersz, jest dla tłumaczy zawsze dużym wyzwaniem. Nie inaczej było w przypadku utworów pojawiających się w omawianym filmie. W swych działaniach translatorskich studenci skupiali się raczej na wiernym przekazaniu informacji zawartych w wierszach. Tak przyjęta strategia, nawet w odniesieniu do wierszy białych, okazała się nietrafiona, a przekłady - zwykle nieudane. Jedynie fragmenty niektórych tłumaczeń można uznać za poprawne. Najlepsze wśród przedstawionych fragmentów jest niewątpliwie tłumaczenie z przykładu 'b'. Prócz oddania sensu wiersza i jego 
klimatu, co w przypadku poezji jest niewątpliwie sprawą najważniejszą, student zachował rymy, liczbę sylab i rytmikę utworu. Pozostałe wiersze zostały poprawione i w podpisach do filmu pojawiły się już ich zmodyfikowane warianty. Fragmenty te były poprawne, jednak daleko im do tłumaczeń wybitnych czy bodaj dobrych, np.:

P. Przysiadt motylek na mojej głowie. Usiadt i siedzi tu w bezruchu.

Przysiadt i patrzy. Jak dobrze i mito siedzieć w tym bezruchu.

Nie jest mi dobrze ani źle, dziwna zaiste to historia.

Motylek po prostu nie wie, gdzie kwiatek, a gdzie ja.

Motylek po prostu nie wie, gdzie ściana jest, gdzie ja.

Prezentowany przekład znalazł się w studenckiej wersji podpisów. Podobnie jak poezja Tolika, tak i ta wersja tłumaczenia nie jest porywająca.

\section{OPRACOWANIE PODPISÓW}

Ostatni etap, a więc dostosowanie przetłumaczonego tekstu do wymogów filmu nie jest, jak by się mogło wydawać, czynnością jedynie czysto techniczną. Wprawdzie wykonane uprzednio tłumaczenie na język polski w wielu fragmentach zostało diametralnie okrojone i zmodyfikowane, jednak proces ten nie mógł być, i z reguły nie był, tylko mechaniczny. Zabiegom skracania tekstu towarzyszyło często podejmowanie różnych decyzji translatorskich, np.

\section{TŁUMACZENIE:}

Teksty pisza nam copywriterzy, ubrania dobieraja styliści, codziennie mamy inne widowisko.

PODPIS:

Tekściarze pisza nam role, styliści ubieraja, codziennie nowe scenki.

\section{TŁUMACZENIE:}

Zrozumienie popetnionego przy wyborze błędu, zajęto mi prawie 20 lat. PODPIS:

Minęto 20 lat, nim zrozumiatem swój błą.

\section{TŁUMACZENIE:}

Każdego swojego nowego pacjenta pytam, czy umie grać w szachy. Jeśli nie umie, to radzę mu się nauczyć, a jak gra, to radzę mu skończyć z tym. 
PODPIS:

Każdego nowego pacjenta pytam o grę w szachy. Jak nie gra, to każę mu zaczać, a gdy gra - przestać.

\section{TŁUMACZENIE:}

Przede wszystkim, w naszym szpitalu, za tydzień, zwalnia się miejsce mojego asystenta. PODPIS:

Za tydzień zwalnia się miejsce mojego asystenta.

\section{TŁUMACZENIE:}

Noszac w sercu miłość i szacunek, zapamiętamy wszystko to, co ona dla nas zrobiła. PODPIS:

Noszą ją w sercu będziemy wspominać wszystko, co zrobiła.

\section{TŁUMACZENIE:}

Wszystko zaczęto się 15 lat temu, kiedy otrzymałam spadek. Stwierdziłam, że muszę mieć własny biznes. I za wszystkie pieniądze jakie miałam, kupiłam... Kupiłam $\dot{Z} u \dot{z} u$.

\section{PODPIS:}

15 lat temu otrzymałam spadek. Chciałam mieć swój biznes, więc za wszystkie pieniądze kupiłam Żużu.

\section{TŁUMACZENIE:}

Teraz jesteśmy jak dwa grzyby, których nikt nie zebrat. PODPIS:

Jesteśmy jak dwa samotne grzyby.

\section{TŁUMACZENIE:}

Chciałem ci od razu powiedzieć, ale potem stwierdziłem, że sam wszystko załatwię, żebyś nie musiała się martwić.

PODPIS:

Chciałem Ci powiedzieć, ale stwierdziłem, że załatwię to sam, żebyś się nie martwiła.

\section{TŁUMACZENIE:}

Od niej mieliśmy szczeniaki, które sprzedawaliśmy.

\section{PODPIS:}

Sprzedawaliśmy szczeniaki, które urodziła. 
Przywołane pary świadczą niewątpliwie o pomysłowości studentów i zrozumieniu zasad, które obowiązują w pracy nad modyfikacją listy dialogowej w języku B i stworzeniem podpisów filmowych.

Podsumowując podnoszone w artykule kwestie, należy stwierdzić, że nauczanie języka obcego realizowane w procesie wykonywania projektu translatorycznego jest nie tylko atrakcyjne dla studentów, wziąwszy pod uwagę różnorodność wykonywanych zadań, ale również przynosi efekty w sferze pogłębiania wiedzy i umiejętności w zakresie opanowania innego systemu językowego. W trakcie pracy nad projektem studenci doskonalili umiejętność słuchania ze zrozumieniem (percepcja warstwy dźwiękowej filmu), pisania oraz tłumaczenia tekstu obcego na język polski. Projekt obnażył wprawdzie braki studentów w pewnych obszarach (problemy z przyswojeniem, rozpoznaniem niektórych elementów wypowiedzi, popełnianie błędów w pisowni, niekiedy niski poziom przekładów), jednakże nie było to coś, czego nie można było szybko skorygować, zwłaszcza że (co wymaga szczególnego podkreślenia) w tych „działaniach naprawczych” wydatny udział brali sami studenci.

Nawiązując do pytania postawionego na wstępie niniejszego tekstu, należy podkreślić, że wykonywany przez studentów projekt opracowania warstwy słownej filmu Звичайна справа W. Wasianowycza wpisuje się w proces nauczania / uczenia się języka ukraińskiego na poziomie odpowiadającym założeniom programowym dla II roku studiów magisterskich; jest to przykład na twórcze i nieco odmienne wykorzystanie przyswojonych kompetencji językowych.

\section{BIBLIOGRAFIA}

Diaz-Cintas J., Dubbing or Subtitling: the Eternal Dilemma, „Perspectives: Studies in Translatology" 1999, nr 7, s. 31-40.

JóźwIKIEWICz P., Przekład a proces nauczania języka ukraińskiego, „Теорія і практика викладання української мови як іноземної” 2007, nr 2, s. 212-218.

LosKa K., Benshi jako wspołautor filmu, „Kwartalnik Filmowy” 2007, nr 57, s. 59-65.

МАсенко Л.Т., Суржик: між мовою $і$ язиком, Київ: Видавничий дім «Києво-Могилянська академія» 2011 [Masenko L.T., Surzhik: mizh movoyu i yazikom, Kï̈v: Vidavnichiy dim «Ki€vo-Mogilyans'ka akademiya» 2011].

Szarkowska A., Przekład audiowizualny w Polsce - perspektywy i wyzwania. „Przekładaniec” 2008, nr 20, s. 18-25.

Tomaszkiewicz T., Przekład audiowizualny. Warszawa: Wydawnictwo Naukowe PWN 2008.

Українська мова. Енциклопедія, Київ: Вид-во „Українська енцклопедія” ім. М.П. Бажана 2004 [Ukraïns'ka mova. Yentsiklopediya, Kiïv: Vid-vo „Ukraïns'ka yentsklopediya” im. M.P. Bazhana 2004]. 


\section{ZASOBY INTERNETOWE}

http://subedit-player.softonic.pl/

http://subworkshop.sourceforge.net/

\section{ЗВИЧАЙНА СПРАВА WALENTYNA WASIANOWYCZA \\ W PRZEKŁADACH STUDENTÓW - SUKCESY I PORAŻKI TRANSLATORYCZNE W ŚWIETLE DYDAKTYKI NAUCZANIA JĘZYKÓW OBCYCH}

\section{Streszczenie}

Proponowany artykuł ma dać odpowiedź na dwa, jakże ważne pytania: czym jest przekład audiowizualny oraz w jaki sposób zajęcia z przekładu audiowizualnego wpisują się w kwestię realizacji konkretnych zadań dydaktycznych, tzn. nauczania języka ukraińskiego na pewnym założonym poziomie. Wykonany przez studentów II roku cyklu magisterskiego projekt tłumaczenia warstwy dialogowej filmu Walentyna Wasianowycza Звичайна справа stał się probierzem ich umiejętności nie tylko w zakresie przekładu, ale i stopnia opanowania języka. W artykule przedstawiono i omówiono zarówno najczęściej pojawiające się błędy, jak również ciekawe rozwiązania translatorskie i sam proces tworzenia podpisów do filmu.

Słowa kluczowe: język ukraiński; przekład audiowizualny; translatoryka; tłumaczenia filmowe; dydaktyka.

\section{ЗВИЧАЙНА СПРАВА ВY VALENTIN VASIANOVYCH IN THE TRANSLATIONS OF THE STUDENTS - TRANSLATION SUCCESSES AND FAILURES IN THE LIGHT OF FOREIGN LANGUAGE TEACHING}

\section{S u m m a r y}

The present article aims at providing an answer to two important questions: what is audiovisual translation and in what do the audiovisual translation classes contribute to the execution of particular teaching tasks, i.e. the teaching of the Ukrainian language at a certain defined level. The project undertaken by the second-year students of Master's programme involved the translation of the dialogue list of the film directed by Valentin Vasianovych „Звичайна справа”. It became the criterion, on the basis of which their skills not only of translation but also of their command of the Ukrainian language were assessed. The article presents the most frequent errors as well as interesting translation solutions and the very process of preparing film subtitles.

Key words: the Ukrainian language; audiovisual translation; translation studies; film translation; didactics. 